\title{
Bilimsel İletişimde Yeşil ve Altın Yollarda Yakınsama ve Türkiye'deki Yansımaları
}

\section{Convergence of the Gold and Green Roads at Scholarly Communication and Reflections on Turkey}

\author{
Korhan Levent ERTÜRK* ve Gökhan ŞENGÜL** \\ Öz
}

Son yıllarda özellikle sosyal ağlarda bilgi dolaşımının artması, gelişmiş mobil iletişim cihazlarının yoğun kullanımı kısıtsız ve farklı ortamlarda bilgi erişim ve paylaşımını gerektirmektedir. Bu bağlamda bilimsel bulguların yer aldığı makalelerin geniş kitlelere ve diğer bilim insanlarının erişimine açılması; hem bilimsel eserin doğruluk ve güvenirliğini artırmaya yardımcı olmakta, hem de bilimsel verinin paylaşılmasını ve dolayısı ile de bilimsel gelişimi olumlu yönde etkilemektedir. Yaklaşık on yıldır bu amaca açık erişim insiyatifi katkı sağlamaktadır. Bu amaçla kendi kendine arşivleme (yeşil yol) ve açık erişim dergisi (altın yol) bilimsel çalışmaların bilim topluluğuna sunulmasında yeni yöntemler olarak takdim edilmiştir

Bu çalışmada; uluslararası alanda yeşil ve altın yollar üzerinde ortaya konan kurallar irdelenmiş, yazar ve yayıncılarının oluşan iklime uyumluluğu sorgulanmış ve Türkiye adresli kurumsal arşiv ve dergilerin ortaya çıkan durum karşısında konumları üzerine bir değerlendirme yapılmıştır. Çalışma esnasında Ulrich Süreli Yayın Rehberi, Thomson Reuters (ISI) Bilimsel Web (Web of Science - WoS) ve Elsevier Scopus uluslararası ticari atıf veri tabanları, RoMEO, Juliet, ve ROARMAP telif politikası rehberleri, OpenDOAR, ROAR kurumsal arşiv rehberleri ve DOAJ açık erişim dergisi rehberi ile ULAKBIM ulusal veri tabanları incelenmiştir.

Anahtar sözcükler: Bilimsel iletişim, Açık erişim, Kurumsal arşivler, Açık erişim dergileri, Atıf veri tabanları

\begin{abstract}
In parallel with the increase of information exchange rate in social networks and the usage of mobile communication devices in recent years, it is also required that the information needs to be shared and freely accessable in different enviroments. In this context freely access to the papers including scientific findings by other scientists and broad population will help to increase both the accuracy and reability of the papers. Besides it will also affect positively the information sharing and scientific improvements. The open access initiative made a great contribution to this object in last ten years. For this purpose self archiving (green road) and open access journal (golden road) are presented as new methods to present scientific research results to community.
\end{abstract}

* Dr.Öğretim Görevlisi; Atılım Üniversitesi Bilişim Sistemleri Mühendisliği Bölümü. (klerturk@atilim.edu.tr)

** Yrd.Doç.Dr.Öğretim Üyesi; Atılım Üniversitesi Bilgisayar Mühendisliği Bölümü. (gsengul@atilim.edu.tr) 
In this study the rules about the green and golden roads in international area is examined first, and adaptation of authors and publishers to golden and green roads are investigated. Then adaptation of Turkey's instutional archives and journals about the golden and green roads are also evaluated. In this study Ulrichsweb, Thomson Reuters Web Of Science (WoS) and Elsevier Scopus databases, RoMEO, Juliet and ROARMAP guides, OpenDOAR, ROAR instutional archives and DOAJ open access journal guidence, and finally ULAKBIM national databases are analysed.

Keywords: Scholarly communication, Open access, Institutional repositories, Open access journals, Citation indexes

\section{Giriş}

Bilimsel iletişim süreci içinde bilim insanları özgün çalışmalarını bilim topluluğuna sunarken, ilişkili disiplinlerde daha önceden yapılan çalışmaları kaynak göstermek suretiyle eserlerinin doğruluk ve güvenirliğini ortaya koymak zorundadır. Bilim insanlarının akademik performansları, hakemli makalelerde yayın yapmanın yanı sıra yayımladıkları makalelerine diğer bilim insanlarının yayımlayacakları eserlerinde atıf yapılması ile koşullandırılmış, entelektüel eserlerinin ne kadarının hakemli dergilerde yayımlandığı, okunduğu ve kullanıldığı ile doğrudan ilişkilendirilmiştir. Bu amaçla yapılan çalışma ve ölçümler çoğunlukla kısıtlı erişimleri olan atıf veri tabanları (dizinleri) üzerinden yapılmaktadır. Bu çalışmalar hakemli dergilerin bilimsel iletişimde önemli bir oyuncu olup olmadığı konusunda önemli ipuçları verirken, bilim insanlarının yayınları için dergi seçiminde önemli rol oynamaktadır (Keresztesi, 1982; Borgman, ve Furner, 2002; Antelman, 2006; Warlick, ve Vaughan, 2007). Uluslararası alanda (Elsevier) Scopus ve Thomson Reuters (ISI) Bilgi Webi (Web of Knowledge) platformu Bilimsel Web (Web of Science - WoS) atıf veri tabanları en bilinenleridir. Türkiye'de ulusal bir atıf veri tabanı oluşturulmakta olup henüz deneme aşamasındadır. Türkiye Akademik Atıf Sistemi $\left(\right.$ TAKA) ${ }^{*}$ muhtemelen 2011 yıl sonu itibariyle hizmete açılacaktır (ULAKBiM, 2011).

Son yıllarda özellikle sosyal ağlarda bilgi dolaşımının artması, gelişmiş mobil iletişim cihazlarının yoğun kullanımı kısıtsız ve farklı ortamlarda bilgi erişim ve paylaşımını gerektirmektedir. Bilimsel iletişimi tüm dinamikleriyle beraber oluşan bu farklı iklim ortamına yansıtmak, bilginin anında görünürlüğü ile doğrudan ilişkilidir. Yaklaşık on yıldır bu amaca açık erişim ( $A E$ - open access - $O A$ ) insiyatifi katkı sağlamaktadır. $A E$, değerlendirme sürecinden geçmiş çalışmaların (özellikle hakemli dergilerde yer alan makalelerin) teknik, zaman ve mekan kısıtlılığı olmaksızın, ücret ödenmeksizin tam metinlerinin (full text) evrensel bir iletişim kanalından (çoğunlukla Internet) görünürlüğünün (serbest erişim ve taranabilirlik) sağlanmasını öngörmektedir (Harnad ve diğerleri, 2004; Tonta 2008). Bu yaklaşıma göre bilimsel çalışmaların yayınlanma ortamları veya farklı sunucular üzerinde serbest erişimi sağlanabilmeli, genel amaçlı arama motorlarınca dizinleme yapılabilmelidir. Bilimsel çalışmaya erişim sağlayan bir

* Bu uygulamanın ulusal ve kurumsal ölçekte bilim politikalarını tespit, değerlendirme ve yönlendirilmesine ayrıca katkı sağlayabileceği değerlendirilmiştir (ULAKBiM, 2011). 
kullanıcı, çalışmadan fiziki ve/veya elektronik çoklu kopya üretebilmeli, çalışmanın esas kaynağını vurgulayarak tamamı yada bir bölümünü paylaşabilmeli hatta bir uygulama platformu/yazılımı içerisinde gömülü olarak kullanabilmelidir (Björk, Roos ve Lauri, 2009). Bu amaçla kendi kendine arşivleme (self archiving) ve açık erişim dergisi (open access journal) bilimsel çalışmaların bilim topluluğuna sunulmasında yeni yöntemler olarak takdim edilmiştir (BOAl, 2011).

Kendi kendine arşivleme (self archiving), çoğunlukla okuyucudan ücret alan dergilerde yayımlanmış makalelerin yazarlarının Web sitelerinde ya da kurumsal açık arşivlerinde orijinal ya da farklı sürümleriyle depolanması ve görünürlüğünün sağlanmasına yöneliktir. Paralel yayıncılık olarak da tanımlanabilen kişisel/kurumsal arşivleme yeşil yol (green road) olarak kodlanmıştır. Yazarın bu yöntemi tercih etmesi, çalışmasını yayımladığı derginin telif sözleşmesinin öngördüğü koşullarıyla doğrudan ilişkilidir. Yazarların telif hakları açısından farkındalığını artırabilmek ve dergi seçiminde kolaylık sağlamak adına yayıncıların telif sözleşmelerini toplu bir şekilde listeleyen projeler yapılmıştır. Örneğin İngiltere'de SHERPA (Securing a Hybrid Environment for Research Preservation and Access - Araştırma, Koruma ve Erişim Çevresi için Güvenlik Desteği) kapsamında 2002 yılından itibaren başlatılan bir proje çerçevesinde RoMEO rehberi (Yayıncı Telif Hakkı Listeleri - Publisher's Copyright Listings) oluşturularak, yayıncıların telif hakkı politikaları Telif Bilgi Bankasına (Copyright Knowledge Bank CKB) kaydedilmeye ve bilim topluluğunun dikkatine sunulmaya başlanmıştır (SHERPA, 2011). RoMEO rehberi yayıncıları yeşil, mavi, sarı, beyaz renkler ile sınıflandırırken, çalışmaları farklı sürümlere ayırmıştır. Yayımlanmış çalışmaların hakemlik sürecini henüz tamamlamamış sürümleri ön baskı sürümü (pre print version), hakemlik sürecini tamamlayıp yayına kabul edilmiş sürümleri ise son baskı (post print version) ya da yayıncı baskısı (publisher version) sürümleri olarak rehberde tarif edilmiştir. Rehberde sarı kodlu yayıncıların ön baskı, mavi kodlu olanların son baskı, yeşil kodlu yayıncıların ise her iki sürümüyle yazarlarının çalışmalarını kişisel/kurumsal arşivlenmesini uygun karşıladıkları belirtilmektedir (Jenkins ve diğerleri, 2007). Böyle bir rehberin yaklaşık 300 yıllık bir abonelik geleneğinden gelen ve gelirlerinin önemli bir bölümünü okuyucu kitlesinden karşılamaya alışkın geleneksel yayıncılar tarafından ne kadar dikkate alındığı, telif sözleşmelerinde yazarların lehine bir iyileştirme yapıp yapmadıkları incelenmekte, yazarlar tarafından rehberin dergi seçiminde ne kadar belirleyici olduğu bilim topluluğunca tartışılmaktadır.

Üniversiteler, çeşitli eğitim ve araştırma kurumları, kurumsal bilgi birikiminin tamamının arşive aktarılması ve bir havuzda toplanması amacıyla zorunlu arşivleme yoluna gitmişlerdir. İngiltere'de tıp alanda yapılan araştırmalar için fon desteği sağlayan WellcomeTrust kuruluşu yazarlarının destek ile tamamlamış oldukları araştırma yazılarını PubMed konu arşivinde yayımlanmasını 2005 yılının sonundan itibaren zorunlu hale getirilmiş̧tir (WellcomeTrust, 2011). SHERPA tarafından geliştirilen JULIET (Araştırma Kuruluşu Arşivleme Politikaları ve Kılavuzları - Research Funders Archiving Mandates 
and Guidelines) rehberinde, yazarlarına fon desteği sağlayan bilimsel araştırma kuruluşlarının yazarları tarafından üretilen bilimsel eserlerinin açık arşivlenmesi ile ilgili politikaları kaydedilmektedir. Bu arşivleme politikalarının belirli standartlar taşıması JULIET tarafından istenmektedir. Standartlar 3 anahtar özelliği ile şöyle ifade edilmektedir: Bilimsel dergilerde yayımlanması kabul edilen bilimsel eser açık arşivde arşivlenmelidir (deposit required), Bilimsel eserin arşivlenecek formatı yayımlanan son kopyası olmalıdır (the full final version), Bilimsel eser, dergiye yayım için kabul edildiği tarihte gecikme (ambargo) olmaksızın açık arşivde depolanmalıdır (when accepted for publication) (SHERPA, 2011). Bilimsel araştırma kuruluşlarına ait arşivleme politikalarının yer aldığı farkıı bir platform ise Eprints tarafından geliştirilen ROARMAP (Açık Arşivler Iç̧erik Arşivleme Arşivleme Politikaları - Registry of OA Repository Material Archiving Policies) olmuştur. Ayrıca 2003 yılından itibaren kurumsal açık arşivleri listeleyen rehberler geliştirilmiştir. Örneğin SHERPA tarafından geliştirilen OpenDOAR ve Eprints tarafından geliştirilen ROAR bunların en bilinenleridir (ROAR, 2011; OpenDOAR, 2011).

Açık erişim dergisi (AED - open access journal - OAJ) makalenin yayım ortamında görünürlüğüne odaklanmıştır. Bu yöntem altın yol (gold road) olarak kodlanmıştır. Yayıncı, sunucularında depolanan makalelere engelsiz erişim hakkı tanımaktadır. Böyle bir uygulamada yayıncılar, okuyucularından gelir edemeyeceği için üstesinden gelmek zorunda oldukları hizmet alımları ve yayın giderleri için farklı ekonomik modeller geliştirmişlerdir. Açık erişim dergilerinde, ödemesiz, sponsor/kurum öder, yazar öder olarak formüle edilen ekonomik modeller görülmüştür (Harnad ve Brody, 2004). Açık erişim dergilerinin görünürlüğünü artırabilmek için sadece hakemli açık erişim dergilerinin yer aldığı ve bu dergilerdeki makalelerin taranabildiği rehberler geliştirilmiştir. Uluslararası kapsamda geliştirilen rehberler içinde 2002 yılında Açık Toplum Enstitüsü'nün desteğiyle İsveç Lund Üniversitesi tarafından hizmete alınan Açık Erişim Dergileri Rehberi (The Directory of Open Access Journals- DOAJ) ve 2006 yılından itibaren Web ortamında sunulan Açık Dergi Kapısı (Open J-Gate) en bilinenleridir (DOAJ, 2011). Ayrıca bölgesel, ulusal ya da konu tabanlı açık erişim rehberleri de Web üzerinde yayınlanmaktadır. Yazarın bu yöntemi seçmesinde çalışmasını yayımlanmasını öngördüğü açık erişim dergisinin bilimsel iletişimde önemli bir oyuncu olup olmadığını bilmesiyle doğrudan bir ilişki olduğu öngörülebilir.

Bu çalışmada; bilimsel iletişimin yeniden yapılandırılmasında farkındalık oluşturan açık erişimli dergiler ve kişisel/kurumsal arşivler ile ilgili son gelişmeler tartışılmakta, güncel yapının uluslararası atıf veri tabanlarına yansıması ile ilgili tespitler yapılmakta, Türkiye adresli dergilerin altın ve yeşil yol üzerinde duruşları incelenmekte, ulusal veri tabanlarının mevcut yapıya yansıması üzerine bir değerlendirme yapılmaktadır.

\section{Önceki Çalışmalar}

Açık erişim için öngörülen yeşil ve altın yolların bilimsel iletişime yansıması Web sayfalarına erişimin başladığı yıllardan itibaren tespit edilmeye başlamıştır. 1990'ı 
yıllarda bazı dergilerin (Psycoloquy, The Public Access Computer Systems Review, The Electronic Journal of Communication gibi) Web ortamında erişilebildiği gözlenmiş, hakemlik sürecine kabul edilmiş ancak değerlendirme süreci henüz tamamlanmamış bir dizi makalenin bir sunucu (ArXiv) üzerinde depolanması ilgi odağı olmuştur. Amerikan Araştırma Kütüphaneleri Derneği'nce (ARL) 1995 yılında Directory of Electronic Journals, Newsletters and Academic Discussion Lists adlı yayında bulunan 105 elektronik dergiden 86 adedinin hakemli olduğu tespiti yapılırken, bu dergilerin 1996 yılından itibaren Web üzerinden kısıtsız erişimi olduğu görülmüştür (Crawford, 2002). Wells (1999), uluslararası alanda süreli yayınları listeleyen Ulrich Süreli Yayın Rehberi (Ulrich's Periodicals Directory - UlrichsWeb)'nde kayıtlı dergilerde 1998'de yayınlanmış makalelerin \%18'inin açık erişimli (193 dergide) olduğunu tespit etmiştir. 1998 ile 2002 arasında yeni yayımlanan hakemli açık erişim dergileri üzerinde yapılan bir araştırmada ise açık erişim dergilerin yaygınlaştığı saptanmıştır (Hedlund, Gustafsson, ve Björk, 2004). Açık erişim dergilerinin etki faktörü farklı çalışmalara konu olmuştur. Harnad (2003), Elsevier'in Tetrahedron dergisine alternatif olarak çıkartılan, Tetrahedron'un yaklaşık dörtte biri fiyatında olan Organic Letters kısa bir süre içinde etki faktöründe Tetrahedron dergisinin önüne geçtiğinin ortaya koymuştur. Kling (2004) çalışmasında açık erişim dergilerinin etki faktörünün sınırlı erişimli ticari dergilere göre daha kısa sürede artış gösterdiğini tespit etmiş, 1992-2003 yılları arasında açık erişim dergilerinde yayınlanan açık erişim makalelerine atıf oranının, olmayanlara (sınırlı erişim) oranla, daha fazla olduğu bilimsel verilerle her disiplin için ortaya koymuştur. Haijem, Harnad ve Gingras (2005) açık erişim makalelerin sınırlı erişimli makalelere oranla büyük üstünlüğüne (en az \%73) dikkat çekmiştir. Atıf veri tabanlarında açık erişimli makale ve dergilerin saptanmasına yönelik 2003 yılında yapılan bir çalışmada ise WoS veri tabanında dizinlenen yaklaşık 23 bin (\%3) makalenin açık erişimli olduğu saptanmıştır (Mc Veigh, 2004).

Yukarıda belirtilen çalışmalar altın yol ile ilgili tespitler için dayanak sağlarken Budapeşte Açık Erişim Girişimi sonrası yeşil yol ile ilgili girişimler başlatılmış ve altın yol ile ilişkilendirilmeye çalışılmıştır. Gadd, Oppenheim ve Probets (2003) tarafından yapılan 80 dergi yayıncısını kapsayan çalışmasında dergilere yeşil*, mavi, sarı, beyaz kod vererek sınıflara ayırmış, yayınlanmış makalelerinin, sarı kodlu dergi yayıncıların (\%9), hakemlik sürecini henüz tamamlamamış (ön baskı - pre print), mavi kodlu olanların (\%9) hakemlik sürecini tamamlayarak yayına kabul edilmiş (son baskı - post print), yeşil kodlu yayıncıların ise (\%24) hem ön baskı hem de son baskı kopyalarıyla kişisel/kurumsal arşivlerde depolanmasını uygun karşıladıklarını tespit etmiştir. Ancak çalışmada yayıncıların yarısından fazlasını kişisel/kurumsal arşivlemeye olumsuz ya da kararsız yaklaşım gösteren (\%58) beyaz kodlu dergiler oluşturmuştur. Bu tip dergi yayıncılarının yazarlarının baskısıyla sektörde oluşacak dinamikler doğrultusunda

\footnotetext{
Burada yeşil olarak ifade edilen kod ile yeşil yol birbirine karıştırılmamalıdır. Yeşil yol yeşil, mavi ve sarı kodların tamamına verilen bir ifadeyi vurgulamaktadır (Yazarların notu).
} 
telif hakkı politikalarını gözden geçirerek kişisel/kurumsal arşivlemeye karşı sıcak bakabileceklerini belirtilmiştir. Harnad ve diğerleri (2004) tarafından yapılan ve 8000 derginin incelendiği bir çalışmada, dergilerin \%5'inin açık erişim dergisi (altın yol) olduğu, \%90 dergi yayıncısının ise yazarlarına makalelerinin kişisel/kurumsal arşivlerde depolanmasına olumlu baktıkları (yeşil yol) tespit edilmiştir. Ancak yazarlar tarafından yayınlanan makalelerin \%20 oranında kişisel/kurumsal arşivlerde depolandığı görülmüştür. Mevcut durumun iyileştirilmesi için yazarların makalelerini kişisel/ kurumsal arşivlemelerini özendirici politikaların oluşturulmasına dikkat çekilmiştir.

Swan ve Brown (2005) tarafından hazırlanan bir raporda bilimsel makalelere, açık erişim dergileri ya da elektronik açık arşivler aracılığıyla erişilebileceği ve değişik amaçlarla kullanılabileceği ifade edilmiştir. Raporda, yazarların büyük çoğunluğunun (\%90) açık erişimin kendileri için bir avantaj olduğunu, yarısından fazlasının (\%55) ise yayınlarını açık erişim dergilerde yayımlamayı tercih ettiklerini belirtmişlerdir. Swan ve Brown, makalesini bir kez açık erişim dergilerinde yayınlatmış olan yazarların \%71 oranında bu uygulamaya devam edeceklerini ifade etmişlerdir. Ancak aynı yazarların kalite kontrolü, kariyeri destekleme, telif hakları ve bilim kurumlarının yayıncılık etkinliklerine zarar verme kaygılarını da taşıdıklarını ortaya koymuşlardır. Kaliforniya Üniversitesinde (ABD), 2006 yılında gerçekleştirilen yaklaşık 1.100 bilim insanını kapsayan bir araştırmada yayınlarının küçük bir bölümünü ise açık erişimli ortama taşıdıkları, büyük çoğunluğunun (\%90) geleneksel yayın politikalarını devam ettirdikleri tespit edilmiştir Üniversitedeki farklı disiplinlerdeki bilim insanlarının yaklaşık üçte biri kurumsal arşivlerde (\%29-31) ön ve son bası olarak, dörtte biri (\%22) ise açık erişimli dergilerde bilimsel eserlerini yayımladığı görülmüştür. Aynı araştırmada bilim insanları, gelecek bir yıl içerisinde yayımlama davranışlarında bir değişiklik olup olmayacağı sorusuna ise \%77 oranında davranış özelliklerini koruyabilecekleri değerlendirilmiştir (Greenhouse, 2007).

2006 yılında kurumsal arşivler için zorunlu arşivleme politikası tanımlanmıştır. Yazarların dergiler tarafından yayınlanmak üzere kabul edilen makalelerinin hakemden geçmiş son halinin zaman geçirmeden bir kurumsal arşivde bulundurulması zorunluluğu olarak ifade edilen politikada makalenin arşivler üzerinde anında ya da gecikmeli açık erişime açma hakkı ise yazara bırakılmıştır. Ayrıca makalelerin zorunlu olarak kurumsal arşivlere konularak açık erişime sunulmasının makalenin etki değerinde olumlu etki yapacağı ifade edilmiştir (Harnad, 2007a). Sale (2006a), yapmış olduğu bir araştırma ile yazarların yayınlarını arşive eklemeyi bir politika ile zorunlu kılan ve bu politikayı aktif olarak uygulayan üç farklı coğrafi bölgedeki kurumsal arşivi incelemiştir. Araştırmada zorunlu arşivleme politikalarının işlevsel hale gelmesinin belli bir süre aldığı ve yazarların ezici bir çoğunlukla çalışmalarını yayınlanmadan önce arşive aktarma eğiliminde olduklarını tespit etmiştir. Özellikle hazırlanan makalelerin yaklaşık altı ay gibi bir gecikme ile dergide basılmasının da bu eğilimi teşvik ettiğinin altı çizmiştir. Sale (2006b) yapmış olduğu farklı bir çalışmada ise kurum bünyesinde aynı anda herkesin 
kurumsal arşivlere yayınlarını aktarmasının bir dizi sorunlar çıkarabileceğini, bölüm bazında kısmi geçişlerle belli bir süre sonunda \%100 katılımı sağlamaya çalışmanın daha verimli bir uygulama olacağını ve zorunlu arşivleme politikalarının bu esaslar doğrultusunda geliştirilmesinin daha uygun olacağını ifade etmiştir. Sale (2006c), bu işin gönüllü politikalarla yürümediğini, zorunlu hale getirildiğinde depolalama oranının hızla \%100'lere yaklaştığını göstermiştir. Harnad (2007b), fon desteği sağlayan araştırma kuruluşu (Funder Mandates) ya da bilim insanına ev sahipliği yapan üniversite ve bilimsel kuruluşun zorunlu arşivleme politikası (Institutional -University Mandates) geliştirilebileceğini, yayıncıların da \%65 oranı ile bu politikaları desteklediklerini, bilim insanlarının ise \%92'sinin zorunlu arşivleme politikasına olumlu yaklaştıklarını ifade etmiştir.

Morris (2006) tarafından yapılan bir çalışmada 1443 açık erişim dergisinin \%85'inin DOAJ açık erişim dergisi rehberinde yer aldığı ve bu dergilerin yıllık ortama 42 makale yayınladığını tespit etmiştir. Aynı yıl 1.350.000 hakemli makalenin yayımlandığı, bu makalelerin yaklaşık \%4,6'sının anında, \%3.5'inin gecikmeli olarak dergilerde açık erişimli olduğu, \%11.3'ünün ise kişisel/kurumsal arşivlerde depolandığı (yeşil yol) tespit edilmiştir. Açık erişimli makaleler toplam makalelerin beşte birini $(\% 19,4)$ oluşturmuştur (Björk, Roos ve Lauri, 2009). ALSP tarafından 2008 yılında yapılan çalışmada farklı bir tablo ortaya konmuştur. Büyük ve ticari yayıncıların, 2005 yılından itibaren yüksek oranda yeni dergi çıkarmaya başladıkları ve yeni dergilerin az sayıda ücretsiz erişime açıldığı çoğunlukla çevrim içi üyelik seçeneği sunulduğu tespit edilmiştir. Ayrıca yazarlarına seçimli olarak açık erişim seçeneği sunan yayınların oranı 2005 yılında \%9 iken bu oran 2008 yılında \%30 olduğu bildirilmiştir. Az sayıda yayıncı, yazarlardan telif hakkı formunu istemekte, bunun yanında çoğunluk yayınlar ise basım için lisans almayı tercih etmektedir. Aynı yıl yapılan farklı bir çalışmada ise 2008 yılında SCOPUS atıf veri tabanından örneklem yoluyla seçilen bir dizi makalenin geliştirilen bir genel arama motoruyle Web üzerinden serbest erişimi denetlenmiştir. Yapılan incelemede seçilmiş 1837 makaleden \%20,4'ünün açık erişimli (\%8,5 açık erişimli dergi, \%11,9 kişisel/ kurumsal arşiv) olduğu saptanmıştır. Yer bilimlerinde en çok (\%33), kimya alanında en az (\%13) açık erişimli makale tespit edilmiştir (Björk ve diğerleri, 2010). DallmeierThiessen ve diğerleri (2010) 2009 yılında DOAJ'da yayın dili 2838 İngilizce olan dergi tespit ederken son iki yılda ortalama 86 makale yayınladıklarını ortaya koymuştur. Yaklaşık 1000 açık erişim dergisi yayıncısına uygulanan bir ankette yayıncıların 2008 yılı için ortalama 31 makale yayınladığı tespiti yapılmıştır (Edgar ve Willinsky, 2010). Laakso ve diğerleri (2011) tarafından yapılan çalışmada ise, 2000 yılında yaklaşık 19.500 olarak tespit edilmiş olan açık erişimli makalenin 2009 yılı itibariyle 191.500 adede, dergi sayısının da 740 dergiden 4769 rakamına ulaştığı tespit edilmiştir. Yukarıda belirtilen çalışmalarda dergilerde tespit edilen açık erişimli makalelerin yıllara göre dağılımı ise (Şekil 1)'de gösterilmektedir. 


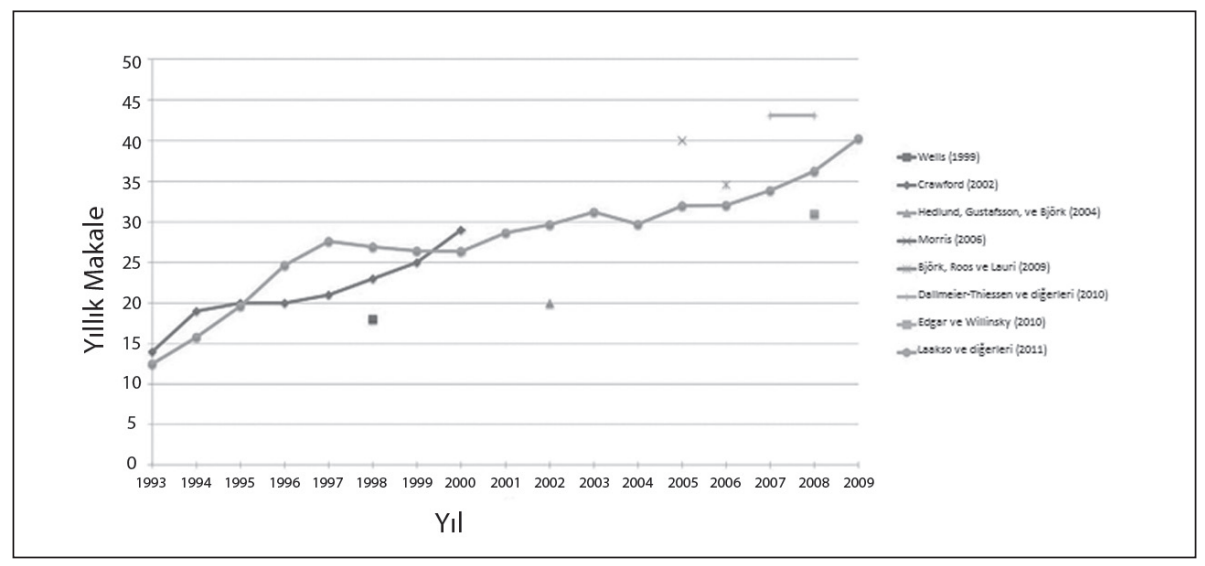

Şekil 1. Açık Erişimli Makale Durumu

Açık erişim Türkiye'de, 2005 yılından itibaren bilim topluluğunun gündemindedir. Farkındalık ve insiyatifler farklı yazarlar tarafından tez, makale ve bildiri çalışmaları ile ortaya konmuştur. Tüm bu çalışmalar Ertürk (2008), Afzali (2009) ve Karasözen, Zan ve Atılgan (2010) tarafından yapılan çalışmalarda özetlenmekte, mevcut durum ortaya konulmakta ve ileriye yönelik önerilerde bulunulmaktadır. Ülkemizde yazar ve yayıncıların yeşil ve altın yollara eğilimleri, geçmiş çalışmalara yansıtılmıştır. Örneğin, Ertürk (2008) tarafından yapılan çalışmada Türkiye'deki bilimsel elektronik dergi yayıncıları, büyük çoğunlukla (\%97) yazarlarının makalelerinin kişisel/kurumsal arşivleme ortamlarında herhangi bir zaman diliminde yayınlanmasına destek verirken, yarısından fazlası (\%55) ise yayının hakemden geçmiş son haliyle (post print) farklı bir yerde bulundurulmasında bir sakınca görmemektedir. Yayıncıların yarısından fazlası (\%55) herhangi bir koşul olmaksızın, \%33'ü dergiye atıf yapılarak, \%9'u da yayıncının iznine gereksinim duyularak arşivleme yapılabilmesini uygun görmektedirler. Ertürk ayrıca Hacettepe Üniversitesindeki yazarların yarısından fazlasının açık erişim farkındalığını ortaya koyarken, büyük çoğunluğunun (\%91) dergilerde yayımlanan makalelerini farklı ortamda yayımına izin verdiklerini ifade etmektedir. Yazarların \%86 oranında bilimsel eserlerinin herhangi bir zaman diliminde, farklı bir ortamda yayınlanması ve çalışmanın farklı bir sürüm yerine orijinal sürümüyle yayınlanmasının daha uygun olacağı hakkında görüşlerini bilim topluluğu ile paylaşmıştır. Köse ve Küçük (2010) tarafından benzer bir çalışmada ise Başkent Üniversitesindeki yazarlar \%54,3'ü yayınlanan yayına atıf yaparak yayınlanabilmesi, \%40'ı yayıncıdan izin alarak olduğu gibi yayınlanabilmesi ve \%20'si ise makalenin olduğu gibi yayınlanabilmesi görüşünü belirtmişlerdir. 


\section{Yöntem}

Bu çalışmada; uluslararası alanda yeşil ve altın yollar üzerinde ortaya konan kurallar irdelenmekte, yazar ve yayıncılarının oluşan iklime uyumluluğu sorgulanmakta ve Türkiye adresli kurumsal arşiv ve dergilerin ortaya çıkan durum karşısında konumları üzerine bir değerlendirme yapılmaktadır. Araştırmamızda aşağıdaki sorulara yanıt aranmaktadır:

$\diamond$ Yayıncılar yeşil yolda yazarlarına verdikleri dersteği uluslararası alanda ilgili platformalara yansıtabilmişler midir?, yazarlar verilen desteği kullanmakta kararlılık gösterebilmişler midir? Altın yoldaki dergiler yazarların ilgisini çekebilmiş midir? Bu dergilerin uluslararası platformalarda yeri nedir? Atıf veri tabanları altın yoldaki dergilere yol üstünlüğü sağlamakta mıdır? Türkiye adresi, altın ve yeşil yollara çıkış vermekte midir?

Çalışmamıza kaynaklık eden verileri sağlamak amacıyla Ulrich Süreli Yayın Rehberi, Thomson Reuters (ISI) Bilimsel Web (Web of Science - WoS) ve Elsevier Scopus uluslararası ticari atıf veri tabanları, RoMEO, Juliet, ve ROARMAP telif politikası rehberleri, OpenDOAR, ROAR kurumsal arşiv rehberleri ve DOAJ açık erişim dergisi rehberi ile ULAKBIM ulusal veri tabanlarında 10 Temmuz - 21 Eylül 2011 tarihleri arasında taramalar gerçekleştirilmiştir. Elde edilen veriler Mssql üzerinde bir veri tabanına aktarılmıştır. Oluşturulan veri tabanında veri grupları arasında ilişkiler yapılandırılarak analizler yapılmış ve ortaya çıkan tablo yorumlanmıştır.

\section{Bulgular ve Yorum}

\section{Uluslararası alanda yeşil ve altın yol yaklaşımı}

Uluslararası alanda süreli yayınları listeleyen Ulrich Süreli Yayın Rehberi (Ulrich's Periodicals Directory - UlrichsWeb)'nde Eylül 2011 itibariyle yaklaşık 637 bin kayıt bulunmaktadır. Kayıtlar incelendiğinde dünya genelinde 251 ülkeye ait 319 bin süreli yayın olduğu görülmektedir. Bu süreli yayınların yaklaşık 52 bin (\%16) adedi aktif ve hakemlidir (Tablo I) (UlrichsWeb.com, 2011). 
Tablo I. Ulrich Süreli Yayın Rehberi Süreli Yayın Durumu

\begin{tabular}{|c|c|c|c|c|c|c|c|c|c|c|}
\hline \multirow{2}{*}{ Süreli Yayın Türü } & \multicolumn{2}{|c|}{ Kayith } & \multicolumn{2}{|c|}{ Akademik } & \multicolumn{2}{|c|}{ Akademik + Aktif } & \multicolumn{2}{|c|}{ Hakemli } & \multicolumn{2}{|c|}{ Aktif + Hakemli } \\
\hline & Adet & $\%$ & Adet & $\%$ & Adet & $\%$ & Adet & $\%$ & Adet & $\%$ \\
\hline Dergi (Journal) & 111.628 & $34,95 \%$ & 97.069 & $70,32 \%$ & 89.483 & $76,50 \%$ & 55.509 & $92,19 \%$ & 51.898 & $92,28 \%$ \\
\hline Dergi (Magazine) & 70.127 & $21,95 \%$ & 1.710 & $1,24 \%$ & 1.471 & $1,26 \%$ & 406 & $0,67 \%$ & 320 & $0,57 \%$ \\
\hline Bildiri (Proceedings) & 5.287 & $1,66 \%$ & 2.171 & $1,57 \%$ & 1.831 & $1,57 \%$ & 570 & $0,95 \%$ & 496 & $0,88 \%$ \\
\hline Özet / Dizin (Abstract / Index) & 1.015 & $0,32 \%$ & 30 & $0,02 \%$ & 25 & $0,02 \%$ & 15 & $0,02 \%$ & 12 & $0,02 \%$ \\
\hline Monografik süreli yayınlar (Monographic series) & 32.760 & $10,26 \%$ & 23.568 & $17,07 \%$ & 20.138 & $17,22 \%$ & 3.523 & $5,85 \%$ & 2.752 & $4,89 \%$ \\
\hline Haber bülteni (Newsletter) & 33.242 & $10,41 \%$ & 1.700 & $1,23 \%$ & 1.240 & $1,06 \%$ & 21 & $0,03 \%$ & 19 & $0,03 \%$ \\
\hline Gazete (Newspaper) & 22.704 & $7,11 \%$ & 176 & $0,13 \%$ & 159 & $0,14 \%$ & 4 & $0,01 \%$ & 4 & $0,01 \%$ \\
\hline Dizin (Directory) & 13.167 & $4,12 \%$ & 245 & $0,18 \%$ & 194 & $0,17 \%$ & 0 & $0,00 \%$ & 0 & $0,00 \%$ \\
\hline Bülten (Bulletin) & 11.822 & $3,70 \%$ & 1.248 & $0,90 \%$ & 1.050 & $0,90 \%$ & 34 & $0,06 \%$ & 33 & $0,06 \%$ \\
\hline Rapor(Report) & 8.165 & $2,56 \%$ & 387 & $0,28 \%$ & 376 & $0,32 \%$ & 46 & $0,08 \%$ & 45 & $0,08 \%$ \\
\hline El Kitabı / Kilavuz (Handbook / Manual) & 5.344 & $1,67 \%$ & 262 & $0,19 \%$ & 256 & $0,22 \%$ & 40 & $0,07 \%$ & 39 & $0,07 \%$ \\
\hline Yilllık (Yearbook) & 2.012 & $0,63 \%$ & 539 & $0,39 \%$ & 496 & $0,42 \%$ & 44 & $0,07 \%$ & 44 & $0,08 \%$ \\
\hline Katalog (Catalog) & 1.262 & $0,40 \%$ & 81 & $0,06 \%$ & 61 & $0,05 \%$ & 0 & $0,00 \%$ & 0 & $0,00 \%$ \\
\hline Veritabanı (Database) & 893 & $0,28 \%$ & 37 & $0,03 \%$ & 37 & $0,03 \%$ & 0 & $0,00 \%$ & 0 & $0,00 \%$ \\
\hline Diğer & 0 & $0,00 \%$ & 8.807 & $6,38 \%$ & 155 & $0,13 \%$ & 0 & $0,00 \%$ & 580 & $1,03 \%$ \\
\hline Toplam & 319.428 & $100 \%$ & 138.030 & $100 \%$ & 116.972 & $100 \%$ & 60.212 & $100 \%$ & 56.242 & $100 \%$ \\
\hline Toplam Süreli Yayın & 319.428 & $50,14 \%$ & 138.030 & $21,67 \%$ & 116.972 & $18,36 \%$ & 60.212 & $9,45 \%$ & 56.242 & $8,83 \%$ \\
\hline Türü Belirsiz & 317.673 & $49,86 \%$ & 499.071 & $78,33 \%$ & 520.129 & $81,64 \%$ & 576.889 & $90,55 \%$ & 580.859 & $91,17 \%$ \\
\hline Toplam Kayıt & 637.101 & $100 \%$ & 637.101 & $100 \%$ & 637.101 & $100 \%$ & 637.101 & $100 \%$ & 637.101 & $100 \%$ \\
\hline
\end{tabular}

Kaynak: UlrichsWeb.com, 2011

Yeşil yolda bilim insanlarına farkındalık sağlayan RoMEO rehberinde 1022 yayıncıya ait 19.622 derginin telif hakkı politikası bulunmaktadır. Ulrichsweb'de kayıtlı olan aktif ve hakemli dergilerin yaklaşık \%40'ının telif hakkı politikası RoMEO rehberinde görüntülenmektedir. Yaptığımız çalışmada RoMEO rehberindeki dergilere ait telif hakkı politikalarının yaklaşık yarısı (9.870) ilk 15 yayıncı tarafından bilim topluluğu ile paylaşılmıştır. Politikaların yaklaşık dörtte üçünün (14.568) ise yayıncıların \%5'ine (59) ait olduğu görülmektedir (Şekil 2). Bu yayıncıların kayıtlı dergi sayıları 50 ve üzeridir. Bu yayıncıların rehber üzerinde belirleyici rol aldıklarını ifade etmek mümkündür.

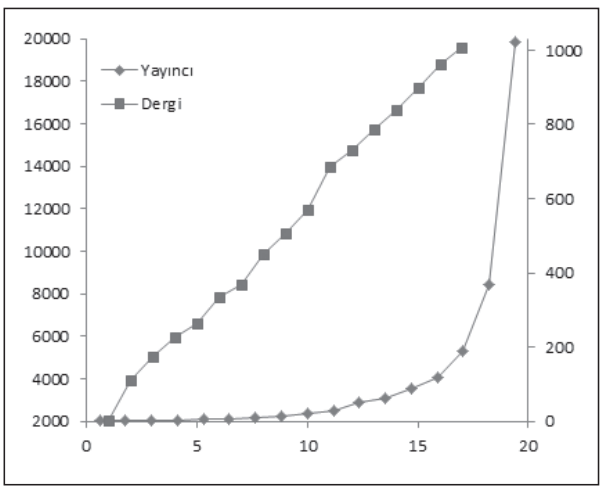

\begin{tabular}{|l|c|c|}
\hline \multirow{2}{*}{ İlk 15 Yayıncı } & \multicolumn{2}{|c|}{ Dergi } \\
\cline { 2 - 3 } & Sıklık & $\%$ \\
\hline Elsevier & 2064 & 10,5 \\
\hline Springer Verlag & 1872 & 9,5 \\
\hline Taylor \& Franci & 125 & 5,7 \\
\hline Wiley-Blackwell & 930 & 4,7 \\
\hline S GE Publications & 600 & 3,1 \\
\hline MAlK Nauk/Interperiodica & 473 & 2,4 \\
\hline Taylor \& Francis & 49 & 2,2 \\
\hline Inderscience & 332 & 1,7 \\
\hline Emerald & 25 & 1,7 \\
\hline Bioinfo Publications & 320 & 1,6 \\
\hline Blackwell Publishing & 308 & 1,6 \\
\hline Cambridge University Press & 288 & 1,5 \\
\hline Hindawi Publishing Corporation & 279 & 1,4 \\
\hline Lippincott, Williams \& Wilkins & 266 & 1,4 \\
\hline Oxford University Press & 259 & 1,3 \\
\hline \multicolumn{1}{|c|}{ Toplam } & $\mathbf{9 8 7 0}$ & $\mathbf{5 0 , 3}$ \\
\hline
\end{tabular}

Şekil 2. RoMEO Rehberi Yayıncı-Dergi Dağılımı 
Kişisel/kurumsal arşivleme desteği veren yayıncılar rehberdeki toplam yayıncıların yaklaşık üçte ikisini (\%64) oluşturmaktadır. Bu yayıncılardan mavi kodlu olanlar \%30, yeşil kodlular \%26, sarı renkliler ise $\% 8$ seviyesinde rehberde temsil edilmektedirler (Şekil 3). Beyaz kodlu yayıncılar ise \%36 seviyesindedir. İlk 15 yayıncıdan 7'si yeşil, 7'si sarı kodludur. Bir yayıncı (Inderscience) ise beyaz kodludur. Rehbere dâhil olan yayıncı sayısı son üç yıl içerisinde yaklaşık \% 300 artış göstermesine rağmen hakemlik sürecini tamamlamış yayına izin veren mavi ve yeşil kodlu yayıncılar rehberdeki yaklaşık \%60 seviyelerini korumuş görünmektedirler.

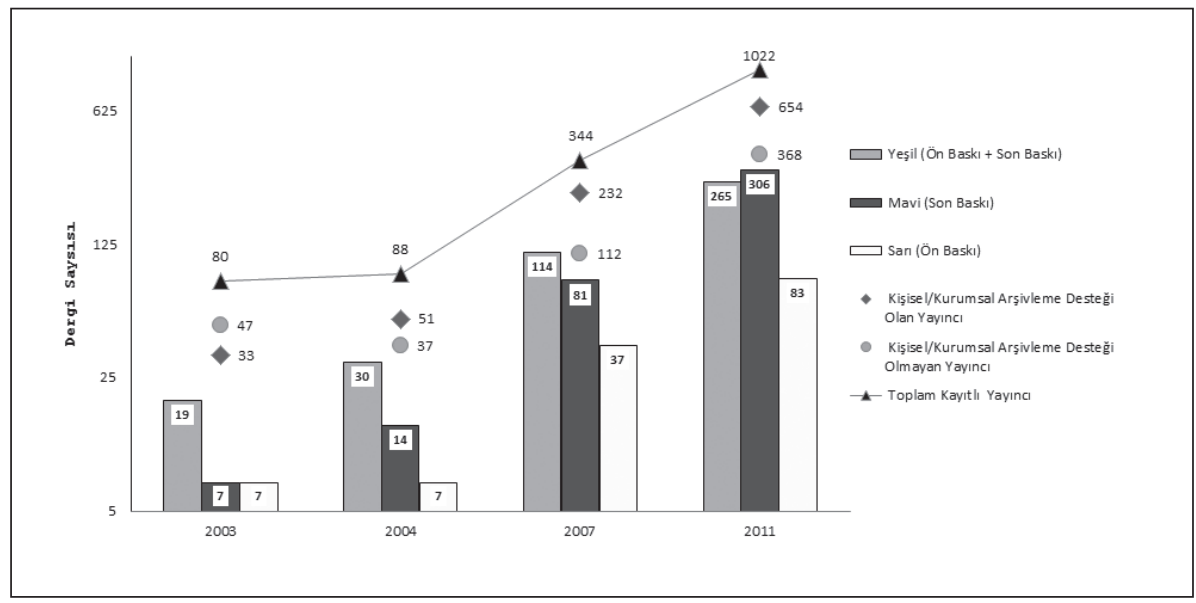

Şekil 3. Yayıncıların Yıllara Göre Telif Hakkı Politikası Dağılımı

Ancak dergiler açısından ortaya daha iyimser bir tablo çıkmaktadır. Beyaz kodlu olan dergiler \%13 seviyesine düşerken kişisel/kurumsal arşivleme desteği veren dergiler \%87 düzeyinde görülmektedir. Renklere göre dağılımda yeşil \%51, mavi \% 9 ve sarı \%27 oranlarıyla temsil edilmektedir (Şekil 4). Ulrichsweb'de kayıtlı olan aktif ve hakemli dergilerin en azından beşte birinin yazarlarına kişisel/kurumsal arşivleme desteği verdiği anlaşılmaktadır. 


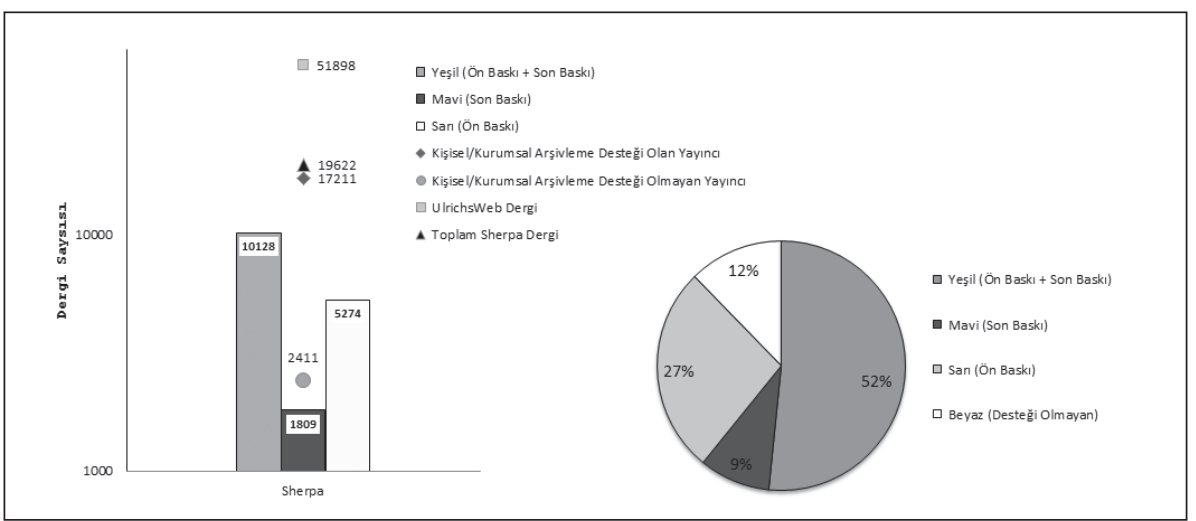

Şekil 4. Dergilerin Telif Hakkı Politikası Dağılımı

RoMEO rehberinde kayıtlı yayıncıların yaklaşık beşte biri (209) makalenin orjinal sürümüyle yayın zamanında (on time) paralel olarak ödemesiz ve kendilerinden izin alınmaksızın farklı Web siteleri ya da AE arşivlerinde depolanması ve paylaşımına destek vermektedir. Bu desteği için az sayıda yayıncı (17) kendilerinden izin alınması, bir diğer grup (5) yazarlarınca ödeme (fee) yapılması halinde koşullu olarak sağlarken bir kısım yayınc (55) ise bir geciktirme süresi (ambargo - delayed) sonrası bu desteği vermektedir (Şekil 5). Ancak zamanında ve ödemesiz desteği sağlayan yayıncılar 2366 dergiyle RoMEO rehberindeki dergilerin \%12'sini temsil etmektedirler.

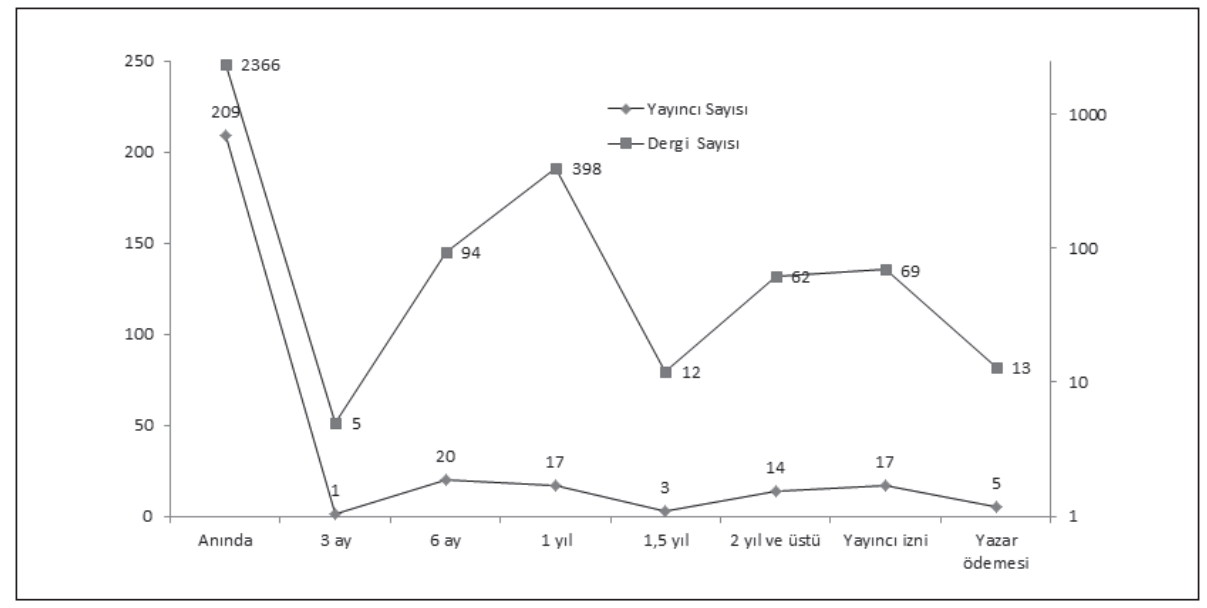

Şekil 5. Yayıncı Ambargo Uygulaması 
Ulrichsweb'deki her dört aktif hakemli dergiden biri (12.511) WoS'da, Ulrichsweb'in yaklaşık \%35'i (18.041) Scopus'da bulunmaktadır. WoS'da dizinlenen dergilerin yaklaşık \%70'inin (8.685) telif sözleşmeleri RoMEO rehberinde kayıtlıdır. Bu rakam RoMEO rehberinin \%45'ine karşılık gelmektedir. RoMEO rehberinde daha iyimser bir tabloyla yaklaşık \%62'sini kapsayan Scopus dizinlediği dergilerin yaklaşık \%66'sı (12.175) ile temsil edilmektedir. Her iki atıf veri tabanında beyaz kodlu yayıncılar ise \%5'ler seviyesinde kalırken, dizinlenen dergilerin en azından \%60'ının yayınlanan makalelere yayın zamanında ya da bir geciktirme sürecinde kişisel/kurumsal arşivleme desteği verdiklerini ifade etmek mümkündür (Şekil 6).

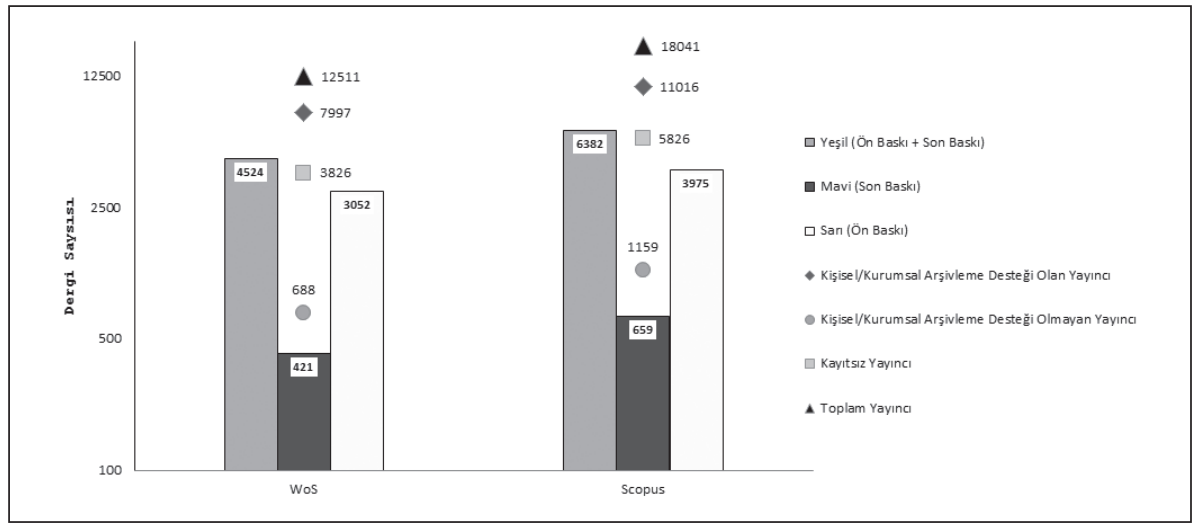

Şekil 6. Atıf Dizinleri Dergi Kişisel/Kurumsal Arşivleme Desteği

Bilimsel araştırma kuruluşlarının kurumsal arşivleme politikalarının yer aldığı ROARMAP'ta 327 üniversite/bilimsel kuruluş kayıt yaptırmış durumdadır. ROARMAP son üç yılda altı kat artış göstermiştir. Ancak uluslararası alanda nitelikli yükseköğretim kurumlarını akademik başarıları doğrultusunda değerlendiren ODTÜ Enformatik Enstitüsü bünyesindeki URAP (University Ranking by Academic Performance) veri tabanında 2000 üniversite/bilimsel kuruluşu yer aldığı dikkate alındığında söz konusu rakamın henüz \%10-15'ler dolayında olduğunu ifade etmek mümkündür. ROARMAP'ta kayıtlı kurumsal arşivlerin arşivleme politikalarınn büyük bölümünün tam zorunlu arşivleme politikası olduğu görülmektedir (Şekil 7). Diğer yandan yazarlarına fon desteği sağlayan bilimsel araştırma kuruluşlarının arşiv politikalarının listelendiği JULIET'de 52 bilimsel kuruluş yer almaktadır. Son üç yıl içerisinde iki kat artış gösteren rehberde çoğunlukla iki anahtar ilkesini (zorunlu arşivleme ve arşivlenecek içerik türü) kapsayan arşivleme politikaları yer almaktadır. JULIET'de zamanında makale yayınlanmasını öngören üçüncü anahtar ilkesini (gecikme/ambargo olmaksızın arşivleme) kabul etmiş kuruluş henüz bulunmayışı dikkat çekicidir. 


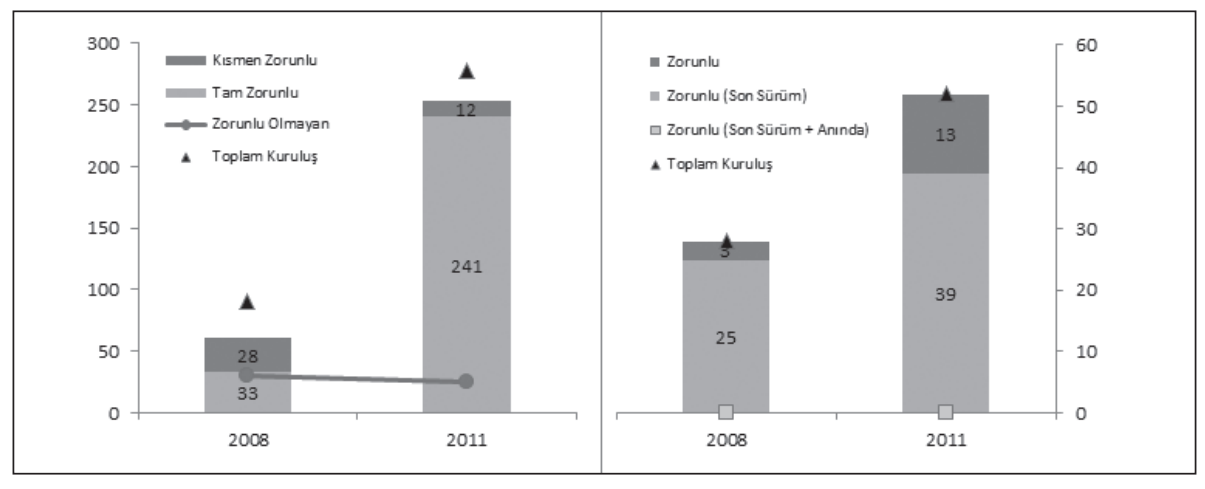

ROARMAP

JULIET

Şekil 7. Rehberlerde Arşivleme Politikası Olan Kuruluş Durumu

Açık arşivlerin listelendiği iki farklı rehberde kurumsal arşiv durumu (Şekil 8)'de görülmektedir. 2000'in üzerinde kurumsal arşivin yer aldığı rehberler son üç yıl içerisinde yaklaşık bir misli artış göstermişlerdir. Yine URAP'ın uluslararası alanda 2000 üniversite/ bilimsel kuruluşunu listelediği dikkate alındığında, bu kuruluşların çoğunluğunda kurumsal arşivlerin yapılandırıldığı görülmektedir.

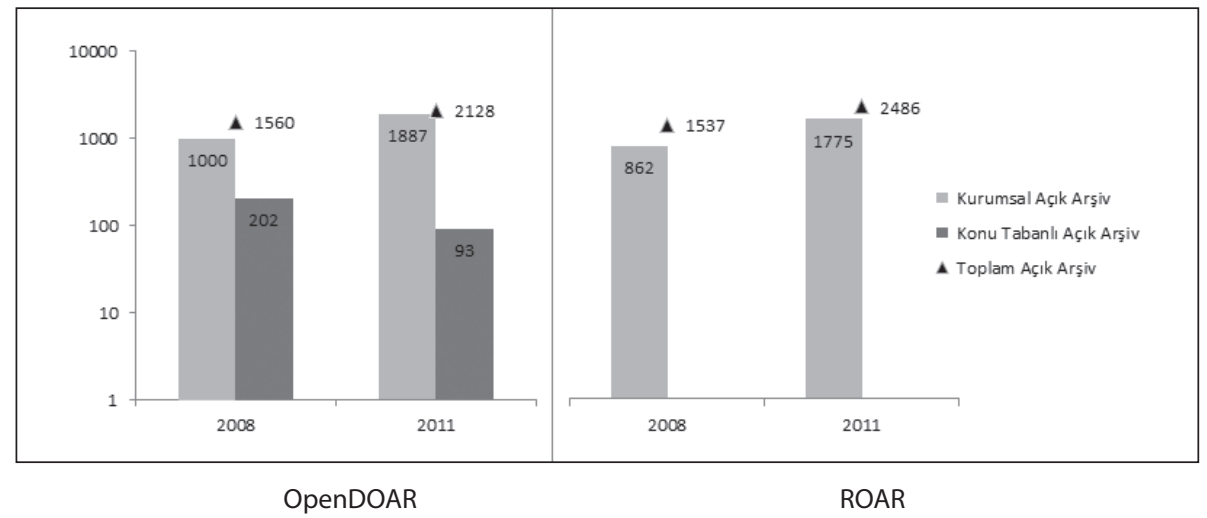

Şekil 8. Rehberlerde Kurumsal Arşiv Durumu

Açık erişim dergilerinin listelendiği DOAJ'da 116 ülkeye ait 203 yayıncının 7.162 dergisi yer almaktadır (DOAJ, 2011). Bu dergilerin altın yolda bulunduklarını ifade etmek mümkündür. Ulrichsweb'deki aktif hakemli dergilerin \%14'ü DOAJ'da listelenmektedir. Ancak UlrichsWeb'de aktif hakemli dergilerin \%12'si (5.757) açık erişimli olarak kayıtlıdır. 
DOAJ'da listelenen dergilerin bir bölümünün (20) henüz UlrichsWeb'de açık erişimli olarak kayıtlı olmadığı görülmektedir. DOAJ rehberinde dergi sayısı son üç yılda yaklaşık \%100 artış göstermiştir (Şekil 9). Üç yıl önce 1.120 dergide yer alan makaleler tam metin (full text) taranabilirken 2011 yılında 3.316 (toplam dergilerin \%45'i) dergi tam metin olarak genel amaçlı arama motorlarında dizinlenmektedir. DOAJ rehberinde ilk onbeş yayıncıya ait dergi sayısı toplam dergilerin yaklaşık onda birini oluşturmaktadır.

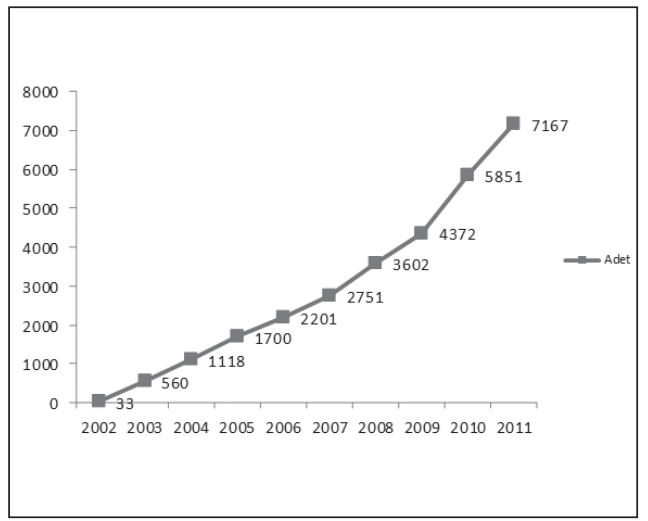

\begin{tabular}{|l|c|c|}
\hline \multirow{2}{*}{ ilk 15 Yayıncı } & \multicolumn{2}{|c|}{ Dergi } \\
\cline { 2 - 3 } & Sıklık & $\%$ \\
\hline Hindawi Publishing Corporation & 230 & $3,2 \%$ \\
\hline Medknow Publications & 93 & $1,3 \%$ \\
\hline Scientific Research Publishing & 83 & $1,2 \%$ \\
\hline Canadian Center of Science and Education & 25 & $0,3 \%$ \\
\hline European Geosciences Union & 25 & $0,3 \%$ \\
\hline Consejo Superior de Investigaciones Científicas & 24 & $0,3 \%$ \\
\hline Asian Network for Scientific Information & 24 & $0,3 \%$ \\
\hline Dove Medical Press & 19 & $0,3 \%$ \\
\hline Gerflint & 17 & $0,2 \%$ \\
\hline BioMed Central & 15 & $0,2 \%$ \\
\hline SpringerOpen & 15 & $0,2 \%$ \\
\hline Springer Verlag & 14 & $0,2 \%$ \\
\hline Universidad Nacional de Colombia & 14 & $0,2 \%$ \\
\hline Bioinfo Publications & 13 & $0,2 \%$ \\
\hline Open Journals Publishing & 11 & $0,2 \%$ \\
\hline Toplam & $\mathbf{6 2 2}$ & $\mathbf{8 , 7} \%$ \\
\hline
\end{tabular}

Şekil 9. DOAJ Rehberi Yıllara Göre Yayın Durumu

DOAJ'da listelenen dergilerin küçük bir bölümü atıf veri tabanlarına yansımaktadır. Dergilerin 996 adedi WoS'da, 2.106 adedi Scopus'ta dizinlenmektedir. Atıf veri tabanlarında, altın yolda duran dergilerinin henüz \%10'lar seviyesinde temsil edildiği görülmektedir. RoMEO rehberinde DOAJ'daki dergilerin tamamına yakınının (\%98) kayıtlı olduğu tespit edilmiştir. Altın yolda olan DOAJ rehberinde dergilerin \%91'i yeşil yol ile ilişkileri bulunmakta, kişisel/kurumsal arşivlemeye destek vermektedir. Geriye kalan dergilerin \%5'inin kişisel/kurumsal arşivlemeye destek vermeyişi dikkat çekicidir (Şekil 10).

DOAJ öncesi farklı yazarlar tarafından yukarıda belirtilen çalışmalar da dikkate alındığında açık erişimli dergi ve makaleler hakkında yaklaşık 20 yıllık bir tablo ortaya konabilmektedir. Özellikle 2008 yılından itibaren görülen artış dikkat çekicidir (Şekil 11). 


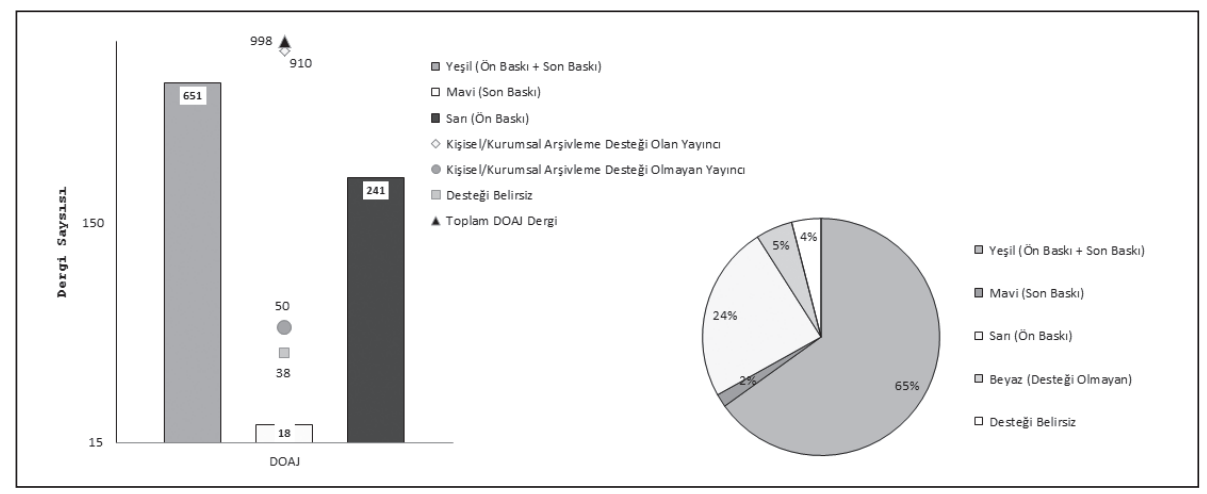

Şekil 10. DOAJ Rehberi Telif Hakkı Politikası Dağılımı

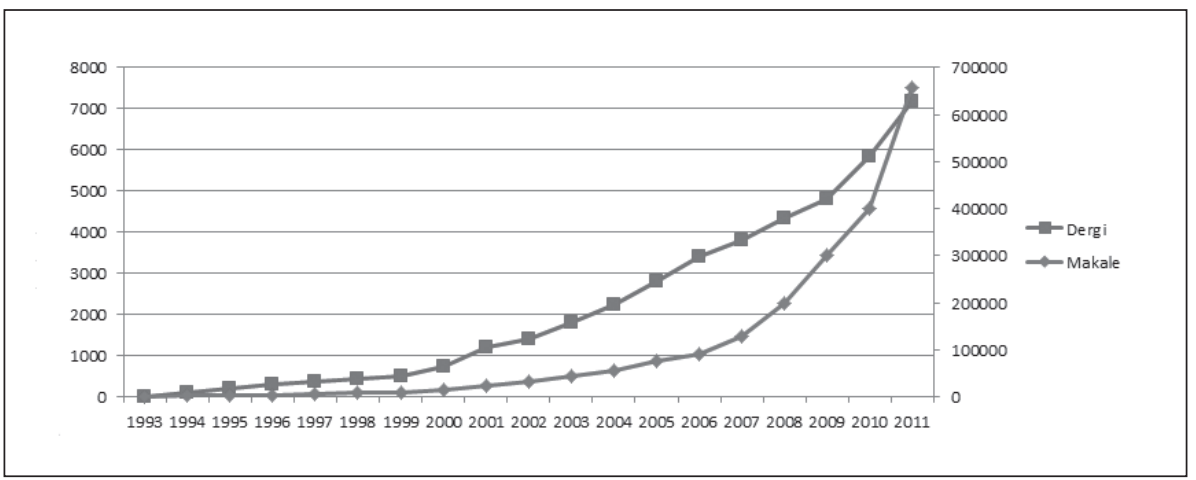

Şekil 11. Açık Erişimli Dergi ve Makaleleri Durumu

\section{Türkiye'deki Yansımalar}

Türkiye İstatistik Kurumu tarafından 2010 yılı için yayınlanan rakamlara göre Türkiye'de 3.679 dergi bulunmakta ve bu dergilerin \%57'si (2.098) ulusal düzeyde yayınlanmaktadır (TÜIK, 2011). Sadece elektronik ortamda bulunan Türkiye adresli bilimsel dergilere ilişkin yapılan bir çalışmada 253 dergi tespit edilmiş ve \%94'ünün ücretsiz, bir başka ifadeyle açık erişimli olduğu tespit edilmiştir. Dergilerin \%60'ının (153 dergi) üniversiteler tarafından üretildiği ortaya çıkarılmıştır. (Küçük ve Olcay, 2006). TAKA'ya veri sağlayacak olan ULAKBIM ulusal veri tabanlarında ise 361 hakemli dergi yer almaktadır (ULAKBIM, 2011).Yaptığımız çalışmada Ulrichsweb'de Eylül 2011 itibariyle Türkiye adresli 1573 süreli yayının kayıtlı olduğu ve bu süreli yayınlardan yaklaşık yarısının (753) dergi olarak olarak yayın hayatını sürdürdüğü tespit edilmiştir. Bu dergilerinde yaklaşık yarısı (370) 
aktif ve hakemlidir (Tablo II) (UlrichsWeb.com, 2011). Ulrichsweb'de kayıtlı 52 bin aktif hakemli derginin yaklaşık binde yedisini Türkiye adresli dergiler oluşturmaktadır.

Tablo II. Ulrich Süreli Yayın Rehberi Türkiye Adresli Yayın Durumu

\begin{tabular}{|c|c|c|c|c|c|c|c|c|c|c|}
\hline \multirow{2}{*}{ Süreli Yayın Türü } & \multicolumn{2}{|c|}{ Kayith } & \multicolumn{2}{|c|}{ Akademik } & \multicolumn{2}{|c|}{ Akademik + Aktif } & \multicolumn{2}{|c|}{ Hakemli } & \multicolumn{2}{|c|}{ Aktif + Hakemli } \\
\hline & Adet & $\%$ & Adet & $\%$ & Adet & $\%$ & Adet & $\%$ & Adet & $\%$ \\
\hline Dergi (Journal) & 831 & $52,83 \%$ & 809 & $92,25 \%$ & 753 & $94,60 \%$ & 406 & $96,90 \%$ & 370 & $97,63 \%$ \\
\hline Dergi (Magazine) & 180 & $11,44 \%$ & 1 & $0,11 \%$ & 1 & $0,13 \%$ & 1 & $0,24 \%$ & 1 & $0,26 \%$ \\
\hline Bildiri (Proceedings) & 7 & $0,45 \%$ & 6 & $0,68 \%$ & 5 & $0,63 \%$ & 3 & $0,72 \%$ & 2 & $0,53 \%$ \\
\hline Özet / Dizin (Abstract / Index) & 0 & $0,00 \%$ & 0 & $0,00 \%$ & 0 & $0,00 \%$ & 0 & $0,00 \%$ & 0 & $0,00 \%$ \\
\hline Monografik süreli yayınlar (Monographic series) & 17 & $1,08 \%$ & 17 & $1,94 \%$ & 16 & $2,01 \%$ & 4 & $0,95 \%$ & 4 & $1,06 \%$ \\
\hline Haber bülteni (Newsletter) & 0 & $0,00 \%$ & 0 & $0,00 \%$ & 0 & $0,00 \%$ & 0 & $0,00 \%$ & 0 & $0,00 \%$ \\
\hline Gazete (Newspaper) & 60 & $3,81 \%$ & 0 & $0,00 \%$ & 0 & $0,00 \%$ & 0 & $0,00 \%$ & 0 & $0,00 \%$ \\
\hline Dizin (Directory) & 0 & $0,00 \%$ & 0 & $0,00 \%$ & 0 & $0,00 \%$ & 0 & $0,00 \%$ & 0 & $0,00 \%$ \\
\hline Bülten (Bulletin) & 32 & $2,03 \%$ & 14 & $1,60 \%$ & 11 & $1,38 \%$ & 0 & $0,00 \%$ & 0 & $0,00 \%$ \\
\hline Rapor(Report) & 0 & $0,00 \%$ & 0 & $0,00 \%$ & 0 & $0,00 \%$ & 0 & $0,00 \%$ & 0 & $0,00 \%$ \\
\hline El Kitabı / Kilavuz (Handbook / Manual) & 4 & $0,25 \%$ & 0 & $0,00 \%$ & 0 & $0,00 \%$ & 0 & $0,00 \%$ & 0 & $0,00 \%$ \\
\hline Yillik (Yearbook) & 1 & $0,06 \%$ & 1 & $0,11 \%$ & 1 & $0,13 \%$ & 0 & $0,00 \%$ & 0 & $0,00 \%$ \\
\hline Katalog (Catalog) & 7 & $0,45 \%$ & 0 & $0,00 \%$ & 0 & $0,00 \%$ & 0 & $0,00 \%$ & 0 & $0,00 \%$ \\
\hline Veritabanı (Database) & 0 & $0,00 \%$ & 0 & $0,00 \%$ & 0 & $0,00 \%$ & 0 & $0,00 \%$ & 0 & $0,00 \%$ \\
\hline Diğer & 434 & $27,59 \%$ & 29 & $3,31 \%$ & 9 & $1,13 \%$ & 5 & $1,19 \%$ & 2 & $0,53 \%$ \\
\hline Toplam & 1.573 & $100 \%$ & 877 & $100 \%$ & 796 & $100 \%$ & 419 & $100 \%$ & 379 & $100 \%$ \\
\hline
\end{tabular}

Kaynak: UlrichsWeb.com, 2011

Ulrichsweb'de yer alan Türkiye adresli aktif hakemli dergilerin yaklaşık üçte biri uluslararası atıf veri tabanlarında dizinlenmektedir. WoS'da 75, Scopus'ta 135 Türkiye adresli aktif hakemli dergi bulunmaktadır. Scopus, WoS'da yer alan Türkiye adresli aktif hakemli dergilerin büyük bir bölümünü (61) kapsamaktadır. Bu dergilerin 58'i (\%16) WoS'da, 86 (\%23) adedi Scopus'ta dizinlenmektedir. ULAKBIM ulusal veri tabanlarında yer alan beş dergiden ancak birinin uluslararası atıf veri tabanlarında dizinlendiğini ifade etmek mümkündür. Ancak atıf veri tabanlarında yer alan Türkiye adresli dergilerin bir bölümü ise ULAKBIM ulusal veri tabanlarında bulunmamaktadır. WoS'da 17, Scopus'ta 49 Türkiye adresli dergi yayıncısının ULAKBIM ulusal veri tabanları için henüz girişimde bulunmayışı dikkat çekicidir.

Yaptığımız çalışmada Ulrichsweb'deki dergiler arasında 4 yayıncıya ait 6 Türkiye adresli derginin telif hakkı politikası RoMEO rehberinde tespit edilmiştir. Bu dergilerin dört adedi ULAKBIM ulusal veri tabanlarında bulunmakta, sadece biri WoS'da dizinlenirken 3 adedi Scopus'ta görülmektedir. Bu dergilerin rehberde yeşil ya da mavi kodları bulunmakta ve gecikme olmaksızın farklı ortamlarda bulundurulması öngörülmektedir (Tablo III). RoMEO rehberinde listelenen Türkiye adresli dergi yayıncılarının tamamı, yazarlarına hakem denetiminden geçmiş sürümlerini kişisel/ kurumsal arşivlerde zamanında depolanması için destek vermektedirler. Türkiye'deki yayıncıların büyük çoğunlukla saklı yeşil yol yolcusu olduğunu ifade etmek mümkündür. Bu yayıncıların farkındalığı artırılarak RoMEO rehberinde Türkiye adresli dergi sayısının hızla yukarıya çekilmesi gerekmektedir. 
Tablo III. Romeo Rehberi Türkiye Adresli Yayınlar

\begin{tabular}{|l|c|c|c|c|c|}
\hline Dergi & Yayıncı & $\begin{array}{c}\text { Romeo } \\
\text { Kod }\end{array}$ & Yayın & Scopus & WoS \\
\hline Türk Patoloji Dergisi & $\begin{array}{c}\text { Patoloji Dernekleri } \\
\text { Federasyonu }\end{array}$ & Mavi & Gecikmesiz & + & + \\
\hline Eğitim ve Bilim & Türk Eğitim Derneği & Mavi & Gecikmesiz & & + \\
\hline $\begin{array}{l}\text { Anadolu Universitesi Bilim ve } \\
\text { Teknoloji Dergisi }\end{array}$ & Anadolu Üniversitesi & Yeşil & Gecikmesiz & & \\
\hline $\begin{array}{l}\text { Turkish Online Journal of } \\
\text { Distance Education }\end{array}$ & Anadolu Üniversitesi & Yeşil & Gecikmesiz & + & \\
\hline $\begin{array}{l}\text { Anadolu Üniversitesi Sosyal } \\
\text { Bilimler Dergisi }\end{array}$ & Anadolu Üniversitesi & Yeşil & Gecikmesiz & & \\
\hline $\begin{array}{l}\text { Psikiyatride Güncel } \\
\text { Yaklaşımlar }\end{array}$ & --- & Mavi & Gecikmesiz & + & \\
\hline
\end{tabular}

Bilimsel araştırma kuruluşlarının telif politikalarının listelendiği JULIET'te Türkiye adresli kuruluş bulunmamakta, ROARMAP'ta ise Türkiye'den sadece ODTÜ yer almaktadır. Telif politikalarını uluslararası alanda paylaşmakta yeterli hasasasiyeti gösteremeyen bilimsel kuruluşlarımız kurumsal arşivlerin listelendiği rehberlerde son üç yıl içerisinde pozisyon aldıkları ve 2011 yılında içerik açısından geçmiş yıllar ile kıyaslanamayacak oranda zenginleştikleri görülmektedir. 2011 yılında içerik sayısı 50 bin rakamını geçmiş görünmektedir. Bu içeriklerin yaklaşık \%22'si makalelelerden oluşmaktadır. Bu tablonun oluşmasında şüphesiz dokuz yeni kurumsal arşivin yıl içerisinde yapılandııımasının önemli rolü olmuştur (Şekil 12).

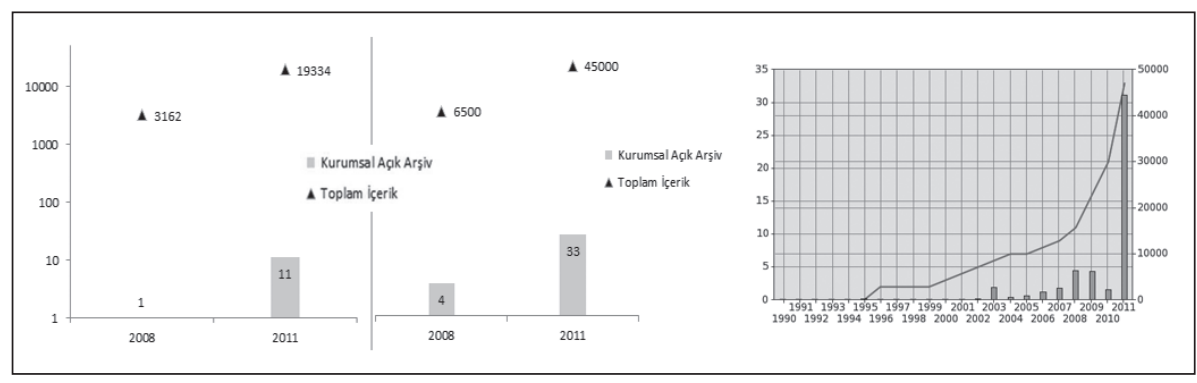

OpenDOAR

ROAR

Şekil 12. Rehberlerde Türkiye Adresli Kurumsal Arşivler Durumu 
Türkiye DOAJ'da 173 açık erişimli dergisi ile 116 ülke arasında 10. sırada yer almaktadır. Ulrichsweb'de ise aktif hakemli ve açık erişimli Türkiye adresli dergiler 153 olarak tespit edilmiştir. Az sayıda derginin (20) Ulrichsweb'de açık erişimli olarak kayıtlı olmadığı anlaşılmaktadır. DOAJ'daki Türkiye adresli dergilerin yarısından fazlası (91) ULAKBIM ulusal veri tabanlarında tespit edilirken, 34'ünün WoS'da 61'inin Scopus'da dizinlendiği görülmektedir. DOAJ'daki Türkiye adresli dergilerden atıf veri tabanlarında dizinlenenlerin bir bölümü ULAKBiM ulusal veri tabanlarında kayıtlı değildir (Tablo IV). Uluslararası atıf veri tabanlarında dizinlenen Türkiye adresli aktif hakemli dergilerin yaklaşık yarısının açık erişimli olduğunu ifade etmek mümkündür.

Tablo IV. DOAJ - ULAKBIM Veri Tabanları İlişkisi

\begin{tabular}{|l|c|c|c|c|c|c|}
\hline Veri Tabanı & Sıklık & $\%$ & WoS & $\%$ & Scopus & $\%$ \\
\hline Mühendislik ve Temel Bilimler & 10 & $11,0 \%$ & 5 & $16,7 \%$ & 9 & $18,8 \%$ \\
\hline Sosyal ve Beşeri Bilimler & 23 & $25,3 \%$ & 1 & $3,3 \%$ & 3 & $6,3 \%$ \\
\hline Tıp & 41 & $45,1 \%$ & 14 & $46,7 \%$ & 26 & $54,2 \%$ \\
\hline Yaşam Bilimleri & 17 & $18,7 \%$ & 10 & $33,3 \%$ & 10 & $20,8 \%$ \\
\hline Toplam & 91 & $100 \%$ & 30 & $100 \%$ & 48 & $100 \%$ \\
\hline
\end{tabular}

\section{Sonuç}

Eylül 2011 itibariyle Ulrichsweb'de 52 bin aktif ve hakemli dergi kayıtlı bulunmakta ve dergilerin yaklaşık \%40'ının telif hakkı politikası RoMEO rehberinde yer almaktadır. Rehbere telif hakkı politikası kaydettiren yayıncı sayısı son üç yıl içerisinde üç kat artış göstermiştir. Bu telif hakkı politikalarının yaklaşık yarısı on beş yayıncıya aittir. Bu yayıncıların yönetiminde en az 50 dergi bulunmaktadır. Bu yayıncılar RoMEO rehberinde belirleyici rol almaktadırlar.

Kişisel/kurumsal arşivleme desteği veren yayıncılar rehberdeki toplam yayıncıların yaklaşık üçte ikisini oluşturmaktadır. Dergiler açısından ortaya daha iyimser bir tablo ortaya çıkmakta, her on dergiden dokuzu kişisel/kurumsal arşivleme desteği vermektedir. Bu destek büyük oranda ambargolu olarak gerçekleşmektedir. Rehberdeki, hakemlik sürecini tamamlamış yayına izin veren mavi ve yeşil kodlu yayıncılar yaklaşık \%60 seviyesindedir. RoMEO rehberinde kayıtlı yayıncıların ancak beşte biri makalenin orjinal sürümüyle yayın zamanında (on time) yeşil yolda duruşuna izin vermekte, dergiler açısından ise bu oran daha da düşerek yaklaşık \%10'lar seviyesinde gerçekleşmektedir.

Ulrichsweb'deki her dört aktif hakemli dergiden biri WoS'da dizinlenirken, yaklaşık üçte biri Scopus'da görüntülenmektedir. Her iki atıf veri tabanındaki dergilerin en 
azından üçte ikisi RoMEO rehberinde kayıtıdır. Her iki atıf veri tabanında beyaz kodlu yayıncılar ise \%5'ler seviyesinde kalırken, dizinlenen dergilerin en azından \%60'ının yayınlanan makalelere yayın zamanında ya da bir geciktirme sürecinde yeşil yolda oldukları görülmektedir.

Yazarlarına fon desteği sağlayan bilimsel araştırma kuruluşlarının arşiv politikalarının listelendiği JULIET'de zamanında makale yayınlanmasını öngören bir politika bulunmamaktadır. ROARMAP'ta ise kayıtlı üniversite/bilimsel kuruluşların büyük çoğunluğu yazarlarına tam zorunlu arşivleme politikası uygulamaktadırlar. Bu rehberdeki kayıtlı kuruluş sayısı son üç yıl içerisinde altı kat artış göstermiş̧tir. URAP'ın üniversite değerlendirmesinde 2000 üniversite/bilimsel kuruluş yer aldığı dikkate alındığında bu desteğin en çok \%15 seviyesinde olduğu görülmektedir.

UlrichsWeb'de listelenen hakemli dergilerin \%14'ü DOAJ rehberinde yer almaktadır. DOAJ rehberindeki dergi sayısı son üç yılda yaklaşık iki katına çıkmıştı. DOAJ rehberinde en çok dergiye sahip yayıncılar, tüm dergilerin yaklaşık \%10'unu yayınlamaktadırlar. DOAJ'da listelenen dergilerin küçük bir bölümü atıf veri tabanlarına yansımaktadır. Atıf veri tabanlarında altın yolda duran dergilerin, DOAJ'da henüz \% $10^{\prime} l a r$ seviyesinde temsil edildiği görülmektedir. DOAJ'daki dergilerin tamamına yakını RoMEO rehberinde kayıtlıdır. DOAJ rehberinde yer alan ve altın yolda olan on dergiden dokuzu yeşil yol ile ilişkilidir ve kişisel/kurumsal arşivlemeye destek vermektedir. Geriye kalan dergilerin \%5'inin kişisel/kurumsal arşivlemeye destek vermeyişi dikkat çekicidir.

Ulrichsweb'de kayıtlı aktif ve hakemli dergilerin yaklaşık binde yedisini Türkiye adresli dergiler oluşturmaktadır. Ulrichsweb'de yer alan Türkiye adresli aktif hakemli dergilerin yaklaşık üçte biri uluslararası atıf veri tabanlarında dizinlenmektedir. Scopus, WoS'da yer alan Türkiye adresli aktif hakemli dergilerin büyük çoğunluğunu kapsamaktadır. ULAKBIM ulusal veri tabanlarında yer alan beş dergiden sadece biri, uluslararası atıf veri tabanlarında dizinlenmektedir. Dikkat çekici bir diğer husus da; atıf veri tabanlarında yer alan Türkiye adresli dergilerin bir bölümünün ULAKBIM ulusal veri tabanlarında bulunmamasıdır. WoS'da 17, Scopus'ta 49 kayıtlı Türkiye adresli dergi yayıncısı ULAKBiM ulusal veri tabanlarında yer almak için henüz girişimde bulunmamıştır.

RoMEO rehberinde Türkiye adresli altı derginin telif politikası yer almaktadır. Bu dergilerin dört adedi ULAKBIM ulusal veri tabanlarında bulunmaktadır. Bunun yanında bu dergilerden sadece biri WoS'da dizinlenirken üç adedi Scopus'ta görülmektedir. Bu dergiler yeşil yolda bulunmakta ve yayınların gecikme olmaksızın farklı ortamlarda bulundurulmasında sakınca görülmemektedir. Türkiye'deki yayıncıların büyük çoğunlukla yazarlarının makalelerinin kişisel/kurumsal arşivleme ortamlarında yayınlanmasına destek verdiği dikkate alınırsa, saklı yeşil yol yolcularının kendilerini uluslararası bilim topluluğuna deklare etmeleri gerekmektedir.

JULIET, bilimsel araştırma kuruluşlarının telif politikalarını listelemektedir. JULIET'te Türkiye adresli kuruluş bulunmazken ROARMAP'ta sadece bir üniversite yer 
almaktadır. Telif politikalarını uluslararası alanda henüz paylaşmamış Türkiye adresli bilimsel kuruluşlar, kurumsal arşivlerin listelendiği rehberlere son üç yıl içerisinde dahil olmuşlar ve 2011 yılında içerik açısından geçmiş yıllar ile kıyaslanamayacak oranda zenginleşmişlerdir. 2011 yılı, dokuzyeni kurumsal arşivin aktif hale getirilmesi ile kurumsal arşivlerimiz açısından bir milat oluşturmuştur. Ülkemizde 172 üniversite olduğu dikkate alınırsa, kurumsal arşivler açısından yolun henüz başında olduğumuz anlaşılmaktadır. Mevcut kurumsal arşivlerin kavramsal ve sayısal durumlarının irdelenmesi, sosyal ağlar üzerinde kurumsal arşivlerin görüntülenebilmesi ve paylaşılabilmesi ile mevcut tablonun iyileştirilmesine katkı sağlayabilecektir.

DOAJ'da Türkiye adresli 173 dergi bulunmaktadır. Bu dergilerin yarısından fazlası (91) ULAKBiM ulusal veri tabanlarında yer alırken, 34'ü WoS'da 61'i Scopus'da dizinlenmiştir. Uluslararası atıf veri tabanlarında dizinlenen Türkiye adresli aktif hakemli dergilerin yaklaşık yarısı açık erişimlidir. Mevcut durum, Türkiye'nin altın yolda iyi bir duruş sergilediğini göstermektedir. Ancak DOAJ'daki Türkiye adresli dergilerden atıf veri tabanlarında dizinlenenlerin bir bölümü, ULAKBIM ulusal veri tabanlarında kayıtlı bulunmamaktadır. TAKA'nın devreye alınması ile altın ve yeşil yolda Türkiye'nin duruşu tam olarak yansıtılamayabilecektir. Konuya taraf olanların bu durumu acilen bir çözüme ulaştırmaları gerekmektedir.

\section{Kaynakça}

Afzali, M. (2009). Türkiye'de Açık Erişim, Kurumsal Arşivler ve Akademik Kütüphaneler. Yayınlanmamış Doktora Tezi. H.Ü. Sosyal Bilimler Enstitüsü. Ankara.

Antelman, K. (2006). Self-archiving practice and the influence of publisher policies in the social sciences. Learned Publishing 19, 85-95. 29 Temmuz 2011 tarihinde http://www.scopus.com adresinden erişildi.

Björk, B. ve diğerleri. (2010). Open access to the scientific journal literature: Situation 2009. PLoS ONE, 5(6). 23 Ağustos 2011 tarihinde http://www.scopus.com adresinden erişildi.

Björk, B-C, Roos, A ve Lauri, M. (2009). Scientific journal publishing: yearly volume and open access availability. Information Research 14. 16 Ağustos 2011 tarihinde http://informationr.net/ir/141/paper391.html adresinden erişildi.

BOAI (2011). Budapest Open Access Initiative. 21 Temmuz 2011 tarihinde http://www.soros.org/ openaccess /initiatives.shtml adresinden erişildi.

Borgman, C.L., ve Furner, J. (2002). Scholarly communication and bibliometrics. Annual Review of Information Science and Technology, 36, 3-72. 19 Eylül 2011 tarihinde http://www.scopus.com adresinden erişildi.

Crawford, W. (2002). Free electronic refereed journals: getting past the arc of enthusiasm. Learned Publishing 15, 117-123. 19Temmuz 2011 tarihinde http://www.scopus.com adresinden erişildi.

Dallmeier-Tiessen, S. ve diğerleri (2010). Open Access Publishing - Models and Attributes Max Planck Digital Library/Informations. 19 Temmuz 2011 tarihinde http://www.scopus.com adresinden erişildi. 
DOAJ (2011). Directory of Open Access Journals. 15 Ağustos 2011 tarihinde http:// www.doaj.org/ adresinden erişildi.

Edgar B. D ve Willinsky, J. (2010). A survey of scholarly journals using Open Journal Systems. Scholarly and Research Communication 06 Ağustos 2011 tarihinde http://www.scopus.com adresinden erişildi.

Ertürk, L. K. (2008). Türkiye'de Bilimsel Illetişim: Bir Açık Erişim Modeli Önerisi. Yayınlanmamış Doktora Tezi. H.Ü. Sosyal Bilimler Enstitüsü. Ankara.

Gadd, E., Oppenheim, C., ve Probets, S. (2003). RoMEO studies 4: An analysis of journal publishers' copyright agreements. Learned Publishing, 16(4), 293-308. 20 Temmuz 2011 tarihinde http:// www.scopus.com adresinden erişildi.

Greenhouse, A. (2007). Faculty Attitudes and Behaviors Regarding Scholarly Communication: Survey Findings from the University of California. 23 Temmuz 2011 tarihinde http://www.osc. universityofcalifornia.edu/ responses/osc.html adresinden erişildi.

Haijem C., Harnad, S. ve Gingras, Y. (2005). Ten year cross disciplinary comparison of the growth of open Access and how it increases research citation impact. IEEE Data Engineering Bulletin 28(4), 39-37. 13 Ağustos 2011 tarihinde http://EPrints.ecs.soton.ac.uk./12906 adresinden erişildi

Harnad, S. (2003). Electronic preprints and postprints. Encyclopedia of Library and Information Science Marcel Dekker, Inc. 23 Temmuz 2011 tarihinde http://www.ecs.soton.ac.uk/ harnad/ Temp/EPrints.htm adresinden erişildi.

Harnad, S. (2007a). The green road to open access: a leveraged transition. Technical Report, ECS, University of Southampton. In: Anna, G.,Eds. The Culture of Periodicals from the Perspective of the Electronic Age, chapter 9, 99-106. L'Harmattan. 02 Ağustos 2011 tarihinde http://EPrints. ecs.soton.ac.uk/13309 adresinden erişildi.

Harnad, S. (2007b). On open access publishers who oppose open access self-archiving mandates. Technical Report, ECS, University of Southampton. 02 Ağustos 2011 tarihinde http://EPrints. ecs. soton.ac.uk/13650/ adresinden erişildi.

Harnad, S. ve diğerleri.(2004). The Access/Impact Problem and the Green and Gold Roads to Open Access: An Update. Serials Review (34), 36-40. 23 Temmuz 2011 tarihinde http://www.scopus. com adresinden erişildi.

Harnad, S. ve Brody, T. (2004). Comparing the impact of open access (OA) vs. non-OA articles in the same journals? D-Lib Magazine, 10(6), 372-383. 05 Ağustos 2011 tarihinde http://dlib.org/dlib/ june04/harnad/06harnad.html adresinden erişildi.

Hedlund, T., Gustafsson, T. ve Björk, B. (2004). The Open Access Scientific Journal: An Empirical Study. Learned Publishing, 17, 199-209. 19 Temmuz 2011 tarihinde http://www.scopus.com adresinden erişildi.

Jenkins, C. ve diğerleri. (2007). RoMEO studies 8: Self-archiving: The logic behind the colourcoding used in the copyright knowledge bank. Program, 41(2), 124-133. 23 Ağustos 2011 tarihinde http://www.scopus.com adresinden erişildi. 
Karasözen, B., Zan, B.U. ve Atılgan, D. (2010). Türkiye'de Açık Erişim ve Bazı Ülkelerle Karşılaştırma. Türk Kütüphaneciliği, 24(2), 235-257

Kaufman-Wills Group LLC (2005). The facts about open access: A study of the financial and nonfinancial effects of alternative business models for scholarly journals. Technical report, ALPSP, Highwire Press and AAAS. 11 Ağustos 2011 tarihinde http://www.alpsp.org/ngen_public/ default.asp? ID=19 Web adresinden erişildi.

Keresztesi, M. (1982). The science of bibliography: Theoretical implications for bibliographic instruction. In C. Oberman\&K. Strauch (Eds.), Theories of bibliographic education (pp. 1-26). NewYork: Bowker.

Kling, R. (2004). The Internet and unrefereed scholarly publishing. Annual Review of Science and Technology, 38:591-631

Köse, G. ve Küçük, M.E.(2010). Açık Erişim Farkındalığı: Başkent Üniversitesi. 2nd International Symposium on Information Management in a Changing World, September 22-24, 2010, Ankara, Turkey. Proceedings içinde (264-272). Ankara: Hacettepe Üniversitesi Bilgi ve Belge Yönetimi Bölümü, 2010

Küçük, M.E. ve N.E. Olcay (2006). Bilimsel Elektronik Dergiler:Türkiye Profili. TÜBiTAK Sosyal Bilimler Araştırma Grubu - Proje No: SOBAG-105K096. Ankara, 2006. (vi, 33 s.)

Laakso, M. ve diğerleri. (2011). The development of open access journal publishing from 1993 to 2009. PLoS ONE, 6(6). 19 Eylül 2011 tarihinde http://www.scopus.com adresinden erişildi.

McVeigh, M.E. (2004). Open Access Journals in the ISI Citation Databases: Analysis of Impact Factors and Citation Patterns-A citation study from Thomson Scientific. 25p. 11 Ağustos 2011 tarihinde http://science.thomsonreuters.com/m/pdfs/openaccesscitations2.pdf adresinden erişildi.

Morris, S. (2006). Personal View: When is a journal not a journal - a closer look at the DOAJ. Learned Publishing 19. 23 Ağustos 2011 tarihinde http://www.scopus.com adresinden erişildi.

OpenDOAR (2011). The Directory of Open Access Repositories. 05 Ağustos 2011 tarihinde http:// www.opendoar.org/ adresinden erişildi.

ROAR (2011). Registry of Open Access Repositories. 01 Ağustos 2011 tarihinde http://roar.eprints. org/ adresinden erişildi.

Sale, A. (2006a). The acquisition of open access research articles. Special Libraries, 11(10), 21 Ağustos 2011 tarihinde http://www.firstmonday.org/issues/issue11_10/sale/index.html adresinden erişildi.

Sale, A. (2006b). The Patchwork Mandate. Working Paper. School of Computing, Australia.

Sale, A. (2006c). Impact of mandatory policies on ETD acquisition. D-Lib Magazine 12(4). 21 Ağustos 2011 tarihinde http://www.dlib.org/dlib/ april06/sale/04sale.html adresinden erişildi.

SHERPA (2011). Research funders' open access policies communication. 23 Ağustos 2011 tarihinde Securing a Hybrid Environment for Research Preservation and Access sitesinden erişildi: http://www.sherpa.ac.uk/juliet/index.php.

Swan, A. ve Brown, S. (2005). Open access self-archiving: Journal authors survey report. Technical report, Joint Information Systems Committee (JISC), UK Key Perspectives Ltd. 23 Eylül 2011 tarihinde www.jisc.ac.uk/uploaded_documents/ACF655.pdf adresinden erişildi. 
Tonta, Y. (2008). Open access and istitutional repositories: The Turkish landscape. In Didar Bayır (Ed.). Turkish Libraries in Transition: New Opportunities and Challenges (pp. 27-47). İstanbul: Turkish Librarians' Association.

TÜiK (2011). 13 Ağustos 2011 tarihinde Türkiye İstatistik Kurumu Web sitesinden erişildi: http:// www.tuik.gov.tr/Start.do

ULAKBIM (2011). 21 Temmuz 2011 tarihinde TÜBiTAK Ulusal Akademik Ağ ve Bilgi Merkezi Web sitesinden erişildi: http:// www.ulakbim.gov.tr/

Warlick, S.E., \& Vaughan, K.T.L. (2007). Factors influencing publication choice: Why faculty choose open access. Biomedical Digital Library, 4, 1. 21 Eylül 2011 tarihinde http://www.scopus.com adresinden erişildi.

WellcomeTrust (2011). Open access policy: Position statement in support of open and unrestricted access to published research. 24 Eylül 2011 tarihinde http://wellcome.ac.uk/About-us/Policy/ Spotlight-issues/Open-access/Policy/index.htm adresinden erişildi

Wells, A. (1999). Exploring the development of the independent, electronic, scholarly journal. Yayınlanmış yüksek lisans tezi, The University of Sheffield. 11 Ağustos 2011 tarihinde http:// panizzi.shef.ac.uk/elecdiss/edl0001/index.html adresinden erişildi. 